\title{
HISTORICAL ASPECTS AND MODERN PERSPECTIVES OF METHODOLOGY OF ENGLISH LANGUAGE TEACHING
}

\section{ІСТОРИЧНІ АСПЕКТИ ТА СУЧАСНІ ПЕРСПЕКТИВИ МЕТОДОЛОГІЇ ВИКЛАДАННЯ АНГЛІЙСЬКОї МОВИ}

\begin{abstract}
This article examines the historical aspects of methods of teaching a foreign language (including English) and ways to find new ways to motivate students to learn foreign languages. We turn to the beginning of the history of teaching methods, its development to today's innovations to achieve effective and creative teaching to students. One of such forms is new pedagogical interactive technologies, the introduction of which promotes effective language learning. The article presents examples of interactive teaching methods that can provide a high level of education appropriate to the tasks and opportunities of the modern world.

In particular, the article raises the most common questions for the methodology - what to study? What are the learning objectives? When does a teacher confidently understand and achieve these goals in the teaching process? How to teach? This is the importance of methodology as a science and the problems it solves.

Next, we highlight the tasks of the teacher in the teaching process, which are the ability to awaken and motivate students' ability to learn, actually inspire students, develop skills through constant repetition of materials and go from simple steps to more complex.

Later in the article we consider historical examples of the work of methodologists from ancient times, such as Eli Donat and Priscian and later works of other scientists. In the process of considering historical facts and methods, we will see how the methodology was formed due to new inventions and technological developments. But at all times and inventions, the basic questions about the effective teaching of foreign languages remain unchanged. The article pays special attention to such scientists as Asher and Lozanov, who worked on how our brain works and the perception of another language. The last part of the article is devoted to interactive teaching of a foreign language (in particular, English), presents practical tasks and summarizes the importance of continuous development of methodology for teaching a foreign language in today's world.

Key words: effective teaching, process of education, pedagogical technologies, interactive learning.
\end{abstract}

у статті розглядаються історичні аспекти методики викладання інозем- ної мови (зокрема, англійськоі) та шляхи пошуку нових прийомів підвищення мотивації студентів до вивчення іноземних мов. Ми звертаємося до початку історії методики викладання, їі розвитку до сьогоденних інновацій щодо досягнення ефективного та креативного викладання студентам. Однією $з$ таких фоорм є нові педагогічні інтерактивні технології, упровадження яких сприяє ефрективному вивченню мови. у статті наведено приклади інтерактивних методів навчання, які здатні забезпечити високий рівень освіти, відповідний завданням і можливостям сучасного світу. Зокрема, у статті поставлені найбільш поширені питання для методології - що вивчати? Які є цілі навчання? Коли викладач впевнено розуміє та досягає цих цілей у прочесі викладання? Як викладати? Уцьому і полягає значення методології як науки та проблеми, які вона вирішує.

Далі ми висвітлюємо завдання викладача у процесі викладання, які полягають в умінні розбудити та мотивувати здібності студентів до навчання, срактично надихати студентів, розвивати навички через постійне повторення матеріалів та йти від простих кроків до більш складних.

Далі у статmі нами розелянуті історичні приклади праці методологів із давніх часів, як-от Елій Донат та Прісціан, пізніші роботи інших учених. У процесі розгляду історичних фрактів та методів ми побачимо, як фоормувалася методика завдяки новим винаходам та розвитку технологій. Але протягом будь-якого часу незмінними залишаються базові питання щодо ефеективного викладання іноземних мов. Особлива увага у статті приділяється таким ученим, як Дж. Ашер та Г. Лозанов, які вивчали те, як працює наш мозок, сприйняття іншої мови. Остання частина статті присвячена інтерактивному викладанню іноземної мови (зокрема, англійськоі), наведені практичні завдання та підсумовано важливість постійного розвитку методології викладання іноземної мови в умовах сучасного світу. Ключові слова: ефрективне навчання, процес навчання, педагогічні технології, інтерактивне навчання.
The goal of the methodology is to enhance the process of teaching English by empowering and helping teachers to work professionally. Learning involves continually reviewing one's own work, the experiences of other teachers, and finding new ways to improve learning.

When teaching a foreign language, the teacher must think about the specific qualities offered to students in a particular mother tongue. This means that the methodology for teaching English must take into account the problems associated with the English language for the students who will be studying.
The methodology of teaching English is associated with a number of difficult tasks or problems:

1. What to Learn? This means that the amount of knowledge, abilities and skills that students must acquire in the process of learning a language.

2. What are the learning objectives? When the teacher is confident in the learning goals, he / she will have the ease of achieving the intended goal.

3. How to teach? In this case, one can recall the principles on which the teaching of the English language is based, the means, methods and tactics used in teaching to achieve the required final completion. 
The answers to these questions define the meaning of methodology as a science. As a consequence, it determines the nature of the problems to be solved.

For successful learning, tutors need several initiatives. The teacher has:

- to awaken and develop the potential and abilities of students for learning;

- to help students develop habits through frequent repetition;

- to inspire student's interest in learning;

- in addition, the teacher must know how to go from simple steps to more difficult ones.

These are the platforms of several language teaching ideas outlined by H.E. Palmer that have proven to be effective even today. And, as Robert Lado emphasized, the following principles should be kept in mind when teaching English:

- Speech before writing.

- Developing skills using a practice template.

- Cultural approach. This last principle is of great importance as it means understanding the language in terms of the meaning of the indigenous population.

A Historical Outline of Language Teaching

"The history of education must have a great future. However, if we ignore the past experience, we will not understand the present or have a view of the future" [1, p. 49].

Firstly, we would like to go back to the history of foreign language teaching.

Foreign language teaching has been practiced for centuries in the teaching of Latin and Greek in England and Europe. Textbooks used in the Middle Ages to teach classical languages were based only on Donatus grammar and Priscianus. Aelius Donatus was a Roman grammar and rhetoric teacher who lived in the middle of the 4'th century. His well-known work Grammatica Ars (Elements of Grammar) was the standard of Latin grammar in the Middle Ages. Priscianus was also a grammar from Mauritania who taught Latin in Constantinople in the 6'th century. His Commentari grammatici was the standard text and it was written in 18 books. He translated into Latin the precepts of the Greeks that seemed appropriate. He often quotes from Virgil Cicero, Plautus and Juvenal. His teaching of grammar was written in the form of a question and answer from the first twelve lines of the Aeneid.

In 1199 Alexander de Villa Dei, grammar and mathematician, created the verse grammars of Priscianus. He published 2645 poems called Doctrinale, perhaps one of the most complete revisions of syntax and grammar. For many centuries, these verses were the only textbook. Alexander de Villa Dei made an intelligible direct translation of the Hebrew Old Testament into Latin. This translation, called the Vulgate of the Bible, made Scripture available to Latin-speaking people in Europe.

During the Renaissance, book printing led to new trends in language teaching. During Henry the Eighth, for example, grammar was taught in schools, however, during his reign, Roger Ascham (1515-1568) introduced a new concept in teaching. He was a Yorkshire scholar and didactic writer and teacher of Latin and Greek to Princess Elizabeth. In his opinion, grammar should have been taught through translation, and not in separate paradigms. His grammar translation was a means of strengthening mental attitudes and discipline.

Grammar method -Translation

Modern foreign languages were studied in a grammar format based on how Latin was previously taught. This method has dominated foreign language research for over 300 years. According to the grammar method of the target language, it is a synthesis of words composed in sentences in accordance with different rules of different languages. Students were required to learn words and grammar rules and build sentences based on them. Words were grouped into lists and rules were memorized in strict order. This language learning system was very rigid. Learning in this way, students were unable to capture the diversity and richness of the spoken language. When a student is faced with real colloquial speech, it is quite different from the artificially constructed sentences to which he is accustomed, and he was completely at a loss. Also, in the 16th century, the first grammar of English as a foreign language appeared. It was called Le Maistre d'Escole Angloise and was written by James Bellot. It contains familiar dialogues for teaching in English. Another work of the same kind was Grammaire Angloise published in 1633 (1662 by Albert H. Marckwardt Old Ways and New Directions in Teaching English by George Mason). These authors brought notes of modernity regarding correct pronunciation and dialogues. They no longer follow the path of synthesis.

Analytical Methods

Next new concepts of language teaching follow. One of them was the analytical method. Proponents of this method were of the opinion that language learning should begin with a written text and its analysis in order to teach the words and rules. The predecessor of this analytical method was Wolfgang Radk or Ratichius (1571-1635). His ideas surpassed the time he lived. According to his concept, everything had to be taught in a logical sequence. The text was first introduced, then the grammar. The first example was given then the rule. There was no memorization. He didn't provide a linguistic explanation either. Instead of presenting coherent texts. These texts were discussed for the first time. Detailed analysis followed, which lead to the learning of words and basic grammatical rules. Obviously, the ability to speak grammar and read your rules strongly differed from the ability to speak and understand language. For him, translation is a valuable skill in itself, but not a substitute for language practice. 


\section{Intuitive method}

Comenius (1592-1671) or Jan Amos Comenius is a name that should not be forgotten, as his ideas revolutionized the teaching of languages. Comenius was born in Moravia in 1592 and is known today as the father of modern education. As for the teaching method, he advocates that spiritual and emotional development are closely related to each other. He proposed an intuitive method based on direct intuition of objects and pictures. Optical and acoustic elements, visual and auditory stimuli, words and images must work together. According to Comenius, the language must be taught like a mother tongue, forcing one to think in it when speaking. In his book Orbis Pictus, Comenius laid the foundation for the intuitive teaching of a foreign language. And his intuitive method meant a transition from outdated concepts to more interesting and effective ones.

Finding new ways

New ways of teaching a foreign language have been introduced in the past century. Jean Jacotau the professor who taught French introduced the procedure for bilingual texts. In his classes, he used a method: he read aloud twice and slowly a text that had already been translated into French. Students will follow the reading in translation in two languages. The students were then asked to divide the text into smaller parts, and then in sentences and in words, and finally into letters and sounds. It was a natural method for him to teach a foreign language. But at the same time there was François Gouin, a professor of Latin who lived in France in the nineteenth century, who pointed out the imperfection of the teaching methods of his time. The story says that he went to Germany to study German and after several unsuccessful attempts to memorize the first verbs and words, then he created a whole book of conversations. However, he was not able to understand or speak German at all, although he studied very diligently. Disappointed, he returned to France and to his great surprise, he learned that his three-year-old nephew could speak much better French than he could speak German. He discovered a new way of learning a foreign language and laid the foundation for a new method called the Gouin series. He noted that teaching foreign languages should start with auditory perception. This means that the main organ for learning is the ear, not the eye. Thus, the best tool for learning a foreign language is what you hear and don't read.

People always express themselves in sentences, so an isolated word cannot be the basis in language learning. In addition, according to Gouin, abstract grammar rules are not used in teaching. Various grammatical categories must be taught by a series of sentences containing appropriate grammatical patterns.

Direct method

In the second half of the 19'th century, controversy over the teaching of a foreign language spawned a reform movement that included ideas to reform the old school system. Teaching English as a second language represents a major impetus. In the last decades of the 19th century, as a result of economic problems in Europe, more and more people tried to start a new life in the USA, Australia and Canada, but especially in the United States of America. Naturally, millions had to learn English quickly and at the same time successfully as a means of communication in the newly chosen country. Since the old methods were not satisfactory, the big problem of reforming the teaching of languages became very important. The general term direct method became popular and proponents of this method emphasized the importance of acquiring a spoken language. Harold E. Palmer, a well-versed linguist, has emphasized how his approach to teaching English is unique. He accurately determined that grammar is not the best way to teach a language. His structured lessons and conversations were called the "oral method". In his classes, he taught English through oral exercises. He believed that the reading material given in class should consist of dialogues and related texts. All descriptions should be light, natural and interesting.

At the same time, the search for new paths continued. The controversy over the teaching of foreign languages went hand in hand with the idea of reforming the old school systems. In classrooms, the native language has become almost completely excluded from teaching English. The concept of imitating the sounds and pronunciation of words and phrases as they sound became much more important. A method that no native language intermediaries use. In this case, as if the native language was completely excluded from teaching, no translation was used. The meaning of words was explained using direct intuition, representation using drawings, paintings that were associated with a foreign word. Abstract concepts were explained by paraphrasing, using synonyms or antonyms, or simply deriving meaning from the text. Correct pronunciation was very important and grammar rules were secondary. Students were given texts and disjointed phrases to prove certain grammatical rules. In 1878 the direct method was applied by M.D. Berlitz and in the 20'th century, the method was introduced in many schools. However, using this method, students will not get used to independent work, and at the same time, the meaning of the words that taught this method of the direct method was not always understood. The direct method has emerged under several names such as the reform method, the new method, and the oral method.

New trends in teaching of foreign languages

Throughout the 20'th century, new theories emerged. Especially in the period from the second half of the 20'th century, from the 50's to the 80's, it was known as the century of methods. Numerous methods have come out in Europe and the USA. Silent 
Way, Total Physical Response, Suggestopedia, methods such as: natural approach, general teaching language, and audio-Lingual approach were recognized.

General physical reaction

Among these new methods, perhaps one of the most interesting is TPR (Total Physical Response), presented by James J. Asher, professor of psychology at the University of San Jose in San Jose, California. In his book "Brain switching", he introduced a stress-free approach to language learning. Influenced by the Nobel laureate Roger Sperry, who put emphasis on the concept, he argued that each hemisphere of the brain can process information independently. Asher did a lot of research on the brain in terms of the concept of the dual tasks of the brain in the process of learning a foreign language. According to Asher, a problem in any practical area of human activity can be a successful method of switching the brain. Switching the brain is characterized by the transfer of some information from one to the other half of the brain. He says: "My hypothesis is that in acquiring a second language, we must first decipher strange sounds through the right hemisphere of the brain while the left hemisphere of the brain is ready to speak" [2, p. 65].

He illustrated the Spanish lesson by pronouncing directions and acting out a movement with students. Then he invited the students to perform the movements alone while listening to the utterances in Spanish. Since neither the conversation itself is required, but only you need to listen to new sounds and act quickly together with the instructor, therefore, a new language, in this way, was acquired through the right hemisphere of the brain. With the right side of the brain already inserted in the statements, it is now possible to understand the new sentence by rearranging the parts [3, p. 57].

TPR Dr Asher offers a very interesting example for Spanish students: "to understand directions in Spanish simulated by the instructor, such as "Walk to the table" and "Sit on a chair. "They were now familiar with statements that were firmly learned through Conversation "body language"'". Students could give appropriate physical responses to familiar directions, and they could understand when the constituent parts recombine to produce a novel, directions such as "Walk to the table and sit at the table?". Although students never did not have the Spanish sentence, "Sit on the table", they usually answered with perfect understanding while sitting on the table [4, p. 36].

There is no doubt that understanding new sentences is perhaps the most important skill when learning in a foreign language, because understanding is the essence of fluency, as Noam Chomsky said. And if the instructor has enough initiative to keep the students' attention consistently, they can quickly move to using the left side of the brain with traditional reading and writing exercises and then back to TPR practice.
Students are not so interested in learning both grammar and phonetics, however they acquire the language without analysis in artificial categories. Students may be able to understand grammar, but they will not know how grammar works. This is because, unlike the left side of the brain, which analyzes everything and so slows down the learning process, the right side of the brain accepts knowledge without any analysis and speeds up the learning process.

TPR has many published papers and studies with sufficient evidence to support the concept of this method, which creates long-term understanding.

The work of George Lozanov

In the history of language teaching, the work of G. Lozanov is popular, who developed a different approach to teaching, based on the eradication of the foundations of uncontrolled work of the brain in learning the grammar of a foreign language.

After years of research in search of new methods to help his students learn faster, the renowned Bulgarian psychologist and educator has achieved some mind-blowing results. He developed a new approach to accelerate learning. He introduced new components of the methods of suggestion and relaxation to teaching. He called these methods Suggestopedia or Suggestive- Inertial Learning Approaches. Suggestopedy or suggestology in pedagogy accelerates language learning. It is a study of the power of suggestion in the study of circumstances. The teacher is responsible for presenting a lot of information in the classroom, while other teaching methods create obstacles and prohibitions for students. The teacher harnesses the power of music, theater and dance. Students listen, watch, and then complete the material taught in the class.

Together with Lozanov, Gateva (E. Gateva), another Bulgarian teacher plays an important role in strengthening the new teaching method. Dr. Gateva had a deep understanding of learning and what she did to combine theories of intelligence with art. For her, learning was much more than cramming. Her work was based on a method that students could learn much faster and remember it for longer.

Her lessons began with classical music such as Mozart and Brahms, and then the teacher read the text decisively and harshly. The lyrics were written in a rhythmic manner, so it had a very powerful effect on what students hear. Then a dialogue reading or a sentence was done in the choir. The phonetic description was done locally. Students will then assume different roles by taking them, taking a look at the translation of the text, and then passing them on to each other so that each of them in the class has a chance to read each role. Pronunciation errors will be tactfully corrected. After completing the reading of the text or dialogues, the teacher removes all translations, but asks the students to translate that very part. In some advanced grades, not all readings are translated; the 
teacher decides which channel should be translated. In the last lessons, only a few words are explained and what is done using synonyms.

This method, we think, involves the act of assessing one's intuition, because sometimes intuition can help students be more courageous when translating. The so-called "playing by ear" actually means an act depending on the circumstances and not several times, when improvisation gives the student the opportunity to make choices, and also allows him to be confident.

A very important factor should be mentioned that Gateva's method has the power of analogy: for example, when reading a sentence, the verb was conjugated in place in the choir. In addition, its relationship to other verbs was explained using new sentences. Always the teacher chose the text that served as the basis for the students to tell their own story.

It is interesting how Lozanov developed his approach to teaching a foreign language. He began to study the fact that information exploded at such a speed that no one could keep the flow on the information field any longer, that no matter what fields you were in, thousands of articles and books were written every year, and therefore people could not absorb extensive information. He became preoccupied with the need to create a new way for people to learn quickly. He found that the two hemispheres of the brain have different functions. He understood that people who could learn quickly were those who could harmonize the work of both hemispheres of the brain. The left and right hemispheres are responsible for certain functions. He found that children under the age of five learn 25 times faster than adults.

In his research, he found that the left hemisphere of the brain is vocabulary, analytical, pragmatic, linear, while the right hemisphere is holistic, artistic, intuitive, annotational, musical. These two hemispheres, in order to work properly, they must be aligned, Lozanov also found out that people have learned wave activity at different levels of the brain. The brain functions at four different levels:

a) Beta level;

b) Alpha level;

c) Theta level;

d) Delta level.

a) The beta level is normal on awakening when we are active and the brain is intense. This is also the time when people find out least effectively.

Modern methods of teaching. Using interactive forms and methods in teaching a foreign language.

Interactive ("Inter" is mutual, "act" - to act) - means interaction, talk, conduct a dialogue with someone. Interactive initiates a more multifaceted interaction of students both with the teacher and with each other, in contrast to active methods. The main function of the teacher in interactive lessons is to direct the activities of students towards achieving the goals of the lesson.
The teacher, of course, develops a lesson plan (usually these are interactive exercises and assignments during which the student studies the material). Consequently, the main components of interactive lessons are interactive exercises and tasks performed by students. The cardinal distinguishing feature of interactive exercises and assignments is that, while completing them, students work on the basis of already studied material as much as possible aimed at learning new things.

Interactive methods make it possible to move away from a monologue teaching system to a dialogue or polylogue, when students not only can freely exchange judgments, their own opinions and assessments of facts, but have the right to argue with the teacher, defending their point of view, position.

Interactive works when the teacher does not express ready-made truths, but organizes the search and discussion by students.

This methodology assumes mutual training of students, which creates a friendly atmosphere of tolerance, security, mutual support, mutual understanding. This allows you to develop the very cognitive activity with the help of high forms of cooperation and cooperation in the process of acquiring new knowledge. The essence of interactive learning is that the educational process involves all students to the maximum in the learning process, so that each participant has the opportunity to understand and reflect on their knowledge and thoughts. Hence, an enormous role is assigned to the individualization of the knowledge of each individual during the joint activities of students in the educational process. The interchange of knowledge, thoughts, methods of activity - this is what interaction offers. During the training sessions, the development of dialogue / polylogical communication takes place, which leads to mutual understanding, interaction, to the joint solution of common, but individually valuable tasks for each participant. Interactive excludes the domination of both one speaker and one opinion over another. As a result, students learn critical thinking, analyzing circumstances and solving complex problems, weighing alternative opinions, making thoughtful decisions, discussing, communicating with other partners. For this, individual, pair and group work is organized in the lessons, research projects, role-playing games are used, work is underway with various information sources, and creative work is used. Along with the traditional (work in small groups, in pairs or triplets, role-playing or business game) forms of work, the interactive method uses techniques such as working in rotary (replaceable) triplets, a carousel, an unfinished sentence, an aquarium, and others.

What are the forms of interactive learning? In modern society, methodologists and practicing teachers have developed many forms of group work for teaching foreign languages. The most common of these 
are Outer Circle, Pinwheel, Fishbowl, Brainstorming, and Debate (names may vary, but the gist is important). These forms are effective only if the lesson discusses a problem in general, about which students have initial ideas based on previous activities and everyday life. In addition, the topics discussed should not be made closed or too narrow. Now let's talk more about learning technologies. The spatial arrangement in the classroom:

- questions in a circle;

- outer circle (chairs in a circle, less prepared children);

- small circle (chairs in a circle, children are more prepared);

- Christmas tree desks (work in groups);

- debate;

- work in groups.

We would mow give an example of Questions in a circle.

"Circle of Ideas" is a form of work, the purpose of which is to resolve acute controversial issues. A list of ideas is being compiled. All students are involved in the discussion of the issue. Groups should perform the same task, consisting of several questions (positions), which are given in turn. In the answers, each of the groups voices only one aspect of the problem, and the teacher continues to ask questions in a circle until the ideas run out. Thus, the possibility of answering all questions in one group is excluded.

"Incomplete sentence" - the students themselves come up with the endings of the sentences.

"Dialogue" - the point is for the groups to find an agreed solution. The result of the work is reflected in the form of a diagram or final text, which is then written down in notebooks. The methodology includes criticism of the position of another group and the search for its strong positions. The experts fix the general views, and at the end of the work they give a generalized answer to the task, which everyone writes down.

Brainstorming is a group method for generating ideas. When conducting a brainstorming session, you need to proceed from the fact that there are no absurd ideas. On the contrary, you need to get as many of these ideas as possible. At the same time, neither ideas nor authors should be evaluated. "Brownian motion" - students, like molecules, randomly move around the office to collect information on a given topic.

"Take a position" - any statement is declared. Students come up to the poster with the words "YES" or "NO". It is preferable that they can explain their position.

"Discussion" - educational group discussions are held on the selected problem in small groups (from 6 to 15 people) of students. The educational discussion differs from other discussions in that the problem under discussion is new only for a group of people participating in the discussion, that is, an already known solution to the problem is to be found in the educational process. The search process should lead to objectively known, but new from the point of view of students, knowledge.

Debate

Ex. After studying the topic "English is the Language of the World", students are invited to share into 2 teams and defend 2 points of view "English is universal Language" vs. "English is not universal Language".

"Decision tree" - the class is divided into several groups with the same number of students. Each group discusses the issue and makes notes on a "tree" (a piece of paper or a blackboard). Then the groups change places and write their thoughts on the trees of their neighbors.

"Shared project" - the groups receive various tasks that illuminate the issue from different angles. After the end of the work, reports are prepared and notes are made on the board. From these records, a general draft is compiled, which is reviewed and supplemented by a group of experts.

"Synthesis of thoughts" is a copy of the previous method with the difference that students make all notes on sheets, which are then passed on to the next group. The worksheet highlights thoughts that the group disagrees with. Experts process the sheets and make a general report, which then discusses the class.

"Search for information" - the method is used to revive dry and uninteresting material. In this case, there is a team search for information that complements the existing one (a teacher's lecture or homework). Subsequently, students answer questions. Answers to questions should be found in textbooks or handouts. Limited time is given to analyze information and search for answers to questions.

Ex. After exploring the topic "The Pleasure of Reading", the reasons for the immense popularity of the Harry Potter saga are investigated.

"Carousel" is a kind of work that children really like. For this, two rings are formed: an internal and an external one. In the inner ring, the students sit motionless. On the outside, they change every 30 seconds. In a few minutes, the students talk over several topics and try to convince the interlocutor of their innocence.

"Aquarium" - the method consists in the fact that several students act out the situation in a circle, and the rest observe and analyze.

Thus, at the moment, a large number of methods and forms of interactive learning have been developed. But every progressive teacher can come up with their own classroom techniques. Most of the listed interactive methods relate to cooperative learning technologies, when students unite to complete assignments, assimilate material and develop communication skills during discussion and argumentation of their positions. A huge advantage of this type of educational activity is that all students in the class are involved in common work. The difficulty lies in the 
ability to organize the activity of students, to introduce them to this type of work as permanent. The methods mentioned in the article can serve as a basis for creating more and more new forms. The interactive creativity of teacher and student is limitless, this is the main advantage of interactive learning.

Thus, in this article we analyzed the methods of foreign language teaching from the beginning to modern innovative and effective interactive ways in order to motivate students in process of foreign language learning.

\section{REFERENCES:}

1. Semlyn Eva. An English Teaching Methodology. Bucuresti : Editura Didactica si Pedagogica Bucuresti, 1967.

2. Braescu I. Modernizarea metodelor de studiere a limbilor straine. Bucuresti : Editura Didactica si Pedagogica, 1966.

3. Asher James. J. Brainswitching A skill for the 21'st Century, Los Gatos, Sky Oaks Productions, INC.,
1988 Georgi Lozanov and Evalina Gateva The Foreign Language Teacher's Suggestopedic Manual. New York : Gordon and Breach Science Publishers, 1988.

4. Levitchi Leon. Manual de Limba Engleza pentru clasa a IX-a. Bucuresti : Editura Didactica si Pedagogica, 1965.

5. Cook John Lennox, Gethin Amorey, Mitchell Keith. A New Proficiency in English, Blackwell, Oxford, 1967 Daniel Jones, An Outline of English Phonetics, Ninth Edition. Cambridge : Heffer \&Sons Ltd., 1960.

6. Palmer H.E. The Principles of Language-Study. London : Oxford University Press, 1965.

7. Lado Robert. Language Teaching: A scientific Approach. New York : Mc. Graw-Hill Inc., 1964.

8. Myasoed T.A. Interactive technologies of learning. Special seminar for teachers. Materials of conferences. M., 2004. 151 p.

9. Panina T.S., Vavilova L.N. Modern ways of educational activization : Monographs. M. : Publishing Center "Academy", 2007. 176 p.

10. Suvorova N. Interactive education: new approaches. M., 2005. 167 p. 